\title{
Assessment of techniques of massage and pumping in the treatment of breast engorgement by thermography
}

\author{
Anita Batista dos Santos Heberle \\ Marcos Antônio Muniz de Moura ${ }^{2}$ \\ Mauren Abreu de Souza ${ }^{3}$ \\ Percy Nohama ${ }^{4}$
}

\begin{abstract}
Objective: to evaluate techniques of massage and pumping in the treatment of postpartum breast engorgement through thermography. Method: the study was conducted in the Human Milk Bank of a hospital in Curitiba, Brazil. We randomly selected 16 lactating women with engorgement with the classification lobar, ampullary and glandular, moderate and intense. We compared the differential patterns of temperature, before and after the treatment by means of massage and pumping. Results: we found a negative gradient of $0.3^{\circ} \mathrm{C}$ of temperature between the pre- and post-treatment in the experimental group. Breasts with intense engorgement were $0.7^{\circ} \mathrm{C}$ warmer when compared with moderate engorgement. Conclusion: massage and electromechanical pumping were superior to manual methods when evaluated by thermography. REBEC: U1111-1136-9027.
\end{abstract}

Descriptors: Thermography; Lactation Disorders; Breast Feeding; Nursing.

${ }^{1}$ MSc, RN, Hospital Universitário Regional de Maringá, Universidade Estadual de Maringá, Maringá, PR, Brazil.

2 Doctoral student, Universidade Tecnológica Federal do Paraná, Curitiba, PR, Brazil. Assitant Professor, Escola Politécnica, Pontifícia Universidade Católica do Paraná, Curitiba, PR, Brazil.

${ }^{3}$ Post-doctoral fellow, Universidade Tecnológica Federal do Paraná, Curitiba, PR, Brasil. Assistant Professor, Escola de Educação e Humanidades, Pontifícia Universidade Católica do Paraná, Curitiba, PR, Brazil.

${ }^{4}$ PhD, Full Professor, Escola Politécnica, Pontifícia Universidade Católica do Paraná, Curitiba, PR, Brazil.

Corresponding Author:

Percy Nohama

Pontifícia Universidade Católica do Paraná. Escola Politécnica

Rua Imaculada Conceição, 1155

Bairro: Prado Velho

CEP: 80215-901, Curitiba, PR, Brasil

E-mail: percy.nohama@gmail.com
Copyright @ 2014 Revista Latino-Americana de Enfermagem This is an Open Access article distributed under the terms of the Creative Commons Attribution Non-Commercial License (CC BY-NC).

This license lets others distribute, remix, tweak, and build upon your work non-commercially, and although their new works must also acknowledge you and be non-commercial, they don't have to license their derivative works on the same terms. 


\section{Introduction}

Mammary engorgement, in the breastfeeding process, is the first symptom encountered by the mother in the self-regulation of the physiology of lactation. Sometimes, the breasts produce a quantity of milk secretion greater than the demand of the child, becoming so full and taut they are called "gable chest"(1), one of the factors of interruption of the exclusive breast feeding (EBF) in children under four months of life ${ }^{(2)}$. Breast engorgement arises from the increased vascularity and accumulation of milk and, secondarily, by lymphatic and vascular congestion(3). Signals arise such as pain, interstitial edema, increase in the volume of the breasts(4), shiny skin, flattened nipples, with or without accompanying diffuse and reddened $\operatorname{areas}^{(3)}$, elevation of the body temperature including a febrile state. After the breasts are emptied(5), a reduction in temperature occurs.

Thermal analysis using images was described by Lehmann, in 1877, and has been used in the health area ${ }^{(6)}$. Thermography is a technique widely used in the industrial sector and still incipient in the medical field even though it is innocuous. It is configured as a method of capturing infrared radiation emitted by a body, determining its temperature ${ }^{(7)}$. Starting from the thermographic inspection, differential patterns of thermal distribution are observed, providing information related to a particular process that is occurring in the body(8), establishing itself up to the present as an auxiliary component for diagnosis $^{(9)}$.

The temperature of the breast undergoes changes due to several factors, among which are the endogenous, which can be studied by means of a thermogram(10). In the research literature, temperature changes in breasts of pregnant women have been observed(11), and hormone dosage in lactating women with engorged breasts, in which it was found that systems with high sensitivity could provide early diagnosis, both of postpartum breast discomfort as well as the evolution of breast engorgement $(B E)^{(12)}$.

Both medicine and nursing use physical examination as a link between art and science. Based on the biological sciences, data are obtained from appropriate tools and the techniques of inspection, palpation and auscultation. Additionally, subjective information is derived from the interview. Thus, the data collected subsidize clinical reasoning in the formulation of the diagnosis ${ }^{(13)}$. Although well known, breast engorgement is understudied(14).
The changes in temperature of the breasts are clearly evidenced, in the case of engorgement, and should be considered for making the diagnosis and in possibilities for treatment. Until now, the literature has not pronounced the existence of this parameter in the study of possible treatments of this condition that affects the nursing mother.

Regarding the application of thermography in the puerperal breast, the encountered studies were old(1112) and some factors contributed to the discrediting of thermography in the 1970s, such as the lack of controlled studies, indertemination of the sensitivity and specificity of the method and the high rate of errors in the interpretation of images. Starting in the 1990s, with the technological advancement of computerized infrared cameras, especially their thermal resolution that can vary from $0.08 \mathrm{mK}$ to $0.03 \mathrm{mK}$ at $30^{\circ} \mathrm{C}$, interest was once again aroused for this method in the clinical area(6).

For breastfeeding women with $\mathrm{BE}$, the physical exam with palpation generally enables identificaton of types of engorgement that most commonly affect these women(15). However, the utilization of technological resources overlaps the subjective nature of palpation in the clnical exam(16).

Regarding the emptying of the breasts, according to existing technical standards for human milk banks (HMB), the Brazilian Network of Human Milk Banks (RBBLH), the extraction should preferably be done by manual pumping, accepting resources such as suction pumps preceded by massage ${ }^{(17)}$. Actually, the most utilized techniques for treatment of breast engorgement are primary, that is, manual techniques, either by the lactating woman herself, a third party, or someone specialized, such as the nurse. Such a procedure is time consuming and stressful for the person performing it. Generally, these professionals remain seated and leaning in the same position for a long time. The spine and the wrists are strained while the hands are moving doing the massage. Also the legs and arms become tired, aching and signs of fatigue emerge ${ }^{(18)}$

Therefore, and targeting both to minimize the ergonomic working conditions of the nursing staff, as well as to bring about elements that denote potential advantages in the use of new technologies, this study aimed to evaluate the application of the mechanical techniques of massaging and pumping in the treatment for $\mathrm{BE}$ in lactation, by means of thermography. 


\section{Methodology}

This research consisted of a clinical study conducted in a controlled and randomized fashion, with a quantiqualitative approach. After bibliographical survey, it was found that there were few reports about evaluation methods of BE in lactation. It was then proposed, using infrared thermography as an experimental technology to assess the results produced by massage and mechanical pumping, since this technique had not been applied in any research similar to this.

The study was conducted in the HMB of the Hospital Universitário Evangélico de Curitiba, Curitiba, Brazil. We randomly selected 16 women (two groups of eight), adults (aged $\geq 18$ ), who sought care at the HMB between the days of January 24 and February 23, 2011. Recruitment occurred after the routine approach was performed by a nurse with extensive experience in breastfeeding, at which time the inclusion and exclusion criteria were identified.

The sample size was calculated based on the population of women with BE treated at the HMB of the hospital. Considering the margin of error of $7 \%$, a confidence level of $95 \%$ and initial estimated prevalence of $50 \%, 196$ volunteers were needed. However, the sample was compromised due to the lack of availability for use of the instrumentation, the acclimatization period required for application of the thermography protocol, and due to not signing the terms of free and informed consent. The volunteers were divided into two groups. By means of systematic random sorting, they were alocated to the control or the intervention group. To do this, the investigator flipped a coin. With the result of "face", the first lactating woman would be in the control group and receive treatment with massage and manual pumping. If it was "crown", the lactating woman belonged to the experimental group and received massage and electromechanical pumping. Thus, the two methods of treatment were alternated starting from the initial random selection.

As inclusion criteria, the following were adopted: volunteers between the third and tenth postpartum Day; moderate and/or intense bilateral encorgement and of any classification as to its location in the breast, according to criteria described in the literature ${ }^{(19)}$. The degree of swelling of the breast were described between the zero grade and the grade four. Thus, it is considered zero grade, a cross, two crosses, three crosses and four crosses progressively to the grades. The tender breast was identified with the zero degree, and the grade four was assigned to the firm, taut and swollen breasts. The remaining degrees of swelling varied between these two extremes $^{(5)}$. In this study, BE was classified according to the intensity of the signs and symptoms: two crosses (light), when the breast presented turgescence without discomfort; three crosses (moderate) denoted weight in the breast with absence of pain; and four crosses (intense) for heavy breast, taut skin and accompanied by pain. We also considered the location of engorgement, which was: (1) lobular, when there was swelling in one or more sparse points of the breast (2) lobar, with stasis of milk accompanied by pain in one or more sparse regions of the breast; (3 ) ampullar, when stasis of milk is delimited to the areolar border, and may be accompanied by pain; (4) glandular, with stasis of milk throughout the mammary gland and pain sensations ${ }^{(15)}$.

Exclusionary criteria included: women with a history of mammoplasty and / or breast prosthesis; use of synthetic oxytocin; use of analgesics in the six hours before the study; use of cream or talc on the breasts on the exam day; bath up until an hour before the study; sunbathing or light in the last two hours prior to the study; history of palpable breast lesion (PBL) or non-palpable; previous history of lactational mastitis; obstructive glandular engorgement; tissue integrity impaired in any region of the breast; and, not accepting the proposed method. The volunteers signed the Terms of Free and Informed Consent and the study was approved by the Ethics in Research Committee of the Pontifícia Universidade Católica do Paraná, under No. 5863.

In the evaluation, two methods were applied: clinical exam and thermographic exam, conducted with the lactating women seated, hands on thighs, facing forwards, including both breasts in a single frontal image. Following the recommendations of Internacional Academy of Clinical Thermology(20), before conducting the exam, the patients disrobed the region under analysis and remained for 15 minutes in the air-conditioned environment in order to have thermal stabilization. The lactating women remained alone in a room of $18 \mathrm{~m}^{3}$, at a temperature between 23 and $24^{\circ} \mathrm{C}, 40$ to $55 \%$ relative humidity, monitored by a table thermo-hygrometer. In the same way, subjects rested for 15 minutes before the acquisition of the images, performed after the application of the treatment techniques (massage and pumping).

The instrument employed in this study was a camera A 325 (FLIR Systems Inc.), with the infrared radiation sensor, that captures the image of the object 
and exhibits with 16-bit resolution, in real time, on a computer screen, at a rate of $60 \mathrm{~Hz}$.

It is worth mentioning that the reference thermogram of the breast in normal lactation had already been acquired by the authors in a previous study. Thus, according to the criteria adopted for other pathologies(21), thermography would be considered an appropriate method after the treatment, the thermogram presented altered color patterns in relation to normal thermal distribution. Also, when the mean of the three areas proposed for analysis in each breast presented a temperature gradient greater than $0.3^{\circ} \mathrm{C}$. Similarly, thermal asymmetry would be considered if there was minimum difference of $0.3^{\circ} \mathrm{C}$ between the breasts.

The techniques adopted for the treatment of the engorged breasts consisted of massage and pumping, using manual techniques for the control group and electromechanical for the experimental group. In this, the vibro-therapeutic massager of the trademark Physical, domestically manufactured, was applied; in the mode of higher vibration and the milking pump of the trademark Medela ${ }^{\circledR}$, manufactured in Switzerland, in maximum suction. For familiarization, the equipment was first applied to the hands of the breastfeeding women and, subsequently, to their breasts.

In the lactating women affected with glandular engorgement, electromechanical (experimental group) or manual (control group) massage was applied for one minute. By means of palpation, we determined whether softening occurred; in the positive cases, pumping was performed prior to the next massage; in negative cases, massage was applied again for another two minutes and pumping took place before the next massage. In cases of lobar, lobular and ampullary engorement, massage was applied to all swollen areas until softening of the region occurred, interspersed with the pumping technique, respectively.

The data were stored in an Excel spreadsheet, and for statistical analysis, SPSS 9.1 software and the $\mathrm{R}$ software was used. To assess the effect of the treatment on each group, the paired t-test was applied. For comparison of the types of engorgement according to the classification for intensity, we applied the F-test of ANOVA for the analysis of variance. For all tests, we fixed the value of $5 \%$ for statistical significance.

\section{Analysis of the thermographic images}

Image analysis began with the identification of the most appropriate marker, and the palette that would provide the best visualization of the areas of interest.
Thus, we selected the marker, Flying spotmeter, the Medical Palette for the analysis of minimum temperature (coldest pixel), and the Palettes Hainhi and Rain10 for the final presentation of the image. For this analysis, we considered the minimum temperatures captured in the coldest pixels contained in the images. This was to avoid the temperature measurement of the vascular system from the surface, cited as an obstacle to the investigation ${ }^{(6)}$.

\section{Results}

We inspected the breasts of the volunteers, it was observed that none of the lactating mothers presented BE of the lobular type. Table 1 shows that the subjects in the experimental group had 50\% glandular engorgement and the same proportion of lobar and lobar / ampullary. In the control group, $62.5 \%$ of the lactating mothers were affected by BE of the lobar and lobar / ampullary areas.

Table 1 - Distribution of breasts according to the breast engorgement by location, within each group, (experimental and control). Curitiba, PR, Brasil, $2011(\mathrm{~N}=16)$

\begin{tabular}{lccccc}
\hline \multirow{2}{*}{$\begin{array}{c}\text { Location of breast } \\
\text { engorgement }\end{array}$} & \multicolumn{2}{c}{$\begin{array}{c}\text { Bxpeasts } \\
\text { group }\end{array}$} & & & \multicolumn{2}{c}{$\begin{array}{c}\text { Control } \\
\text { group }\end{array}$} \\
\cline { 2 - 3 } \cline { 5 - 6 } & $\mathbf{n}$ & $\%$ & & $\mathbf{n}$ & $\%$ \\
\hline Glandular & 4 & 50 & & 3 & 37.5 \\
Lobar and lobar/ampullary & 4 & 50 & & 5 & 62.5 \\
Total & 8 & 100 & & 8 & 100 \\
\hline
\end{tabular}

In this research, seven breastfeeding women were affected by glandular engorgement, four of moderate type and three of the intense type. In comparison of the right breast with the left, according to the classification of intensity of engorgement, before treatment, with the intent of verifying if there were temperature differences between these two types of engorgement. We applied here the F-test of analysis of variance ANOVA, and the results denoted a significant difference between breast with moderate and intense $\operatorname{BE}(p=0,0119)$. When comparing the left breast with the right, we did not observe significant differences.

In Figure 1, it was verified that the breasts with moderate engorgement had a mean temperature of $34.8^{\circ} \mathrm{C}$ versus $35.5^{\circ} \mathrm{C}$ for those with intense engorgement. 


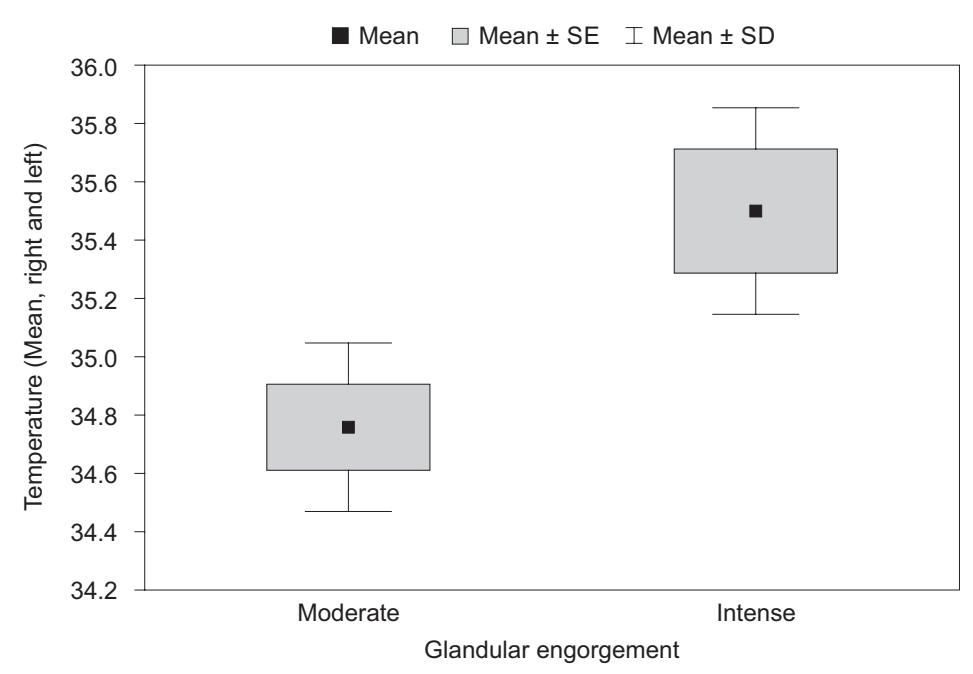

Figure 1 - Comparison of the temperature between breasts with moderate and intense engorgement before treatment, among the two groups

In this step, the temperature of the breasts was compared both in the control group and the experimental group, before and after the intervention, in order to identify differences in temperature. To this end, the paired t-test was used, and the results are described in Table 2.

It was found that, at the $5 \%$ level of significance, there was a significant difference between the temperature variations between the pre and post treatment in the experimental group. In the control group, there was no significant difference.

Table 2 - Comparison of the temperature between the control group and the experimental group, before and after treatment

\begin{tabular}{lccc}
\hline Group & $\begin{array}{r}\text { Pre-treatment } \\
\text { mean }\left({ }^{\circ} \mathrm{C}\right)\end{array}$ & $\begin{array}{c}\text { Post-treatment } \\
\text { mean }\left({ }^{\circ} \mathrm{C}\right)\end{array}$ & p-value \\
\hline Control & 35.2 & 35.3 & 0.8153 \\
Experimental & 34.8 & 34.5 & 0.0349 \\
\hline
\end{tabular}

Paired t-test

In Figure 2, is illustrated in the photo and thermogram of the left breast of a volunteer, the external lateral view. Surrounding the points listed, we observed the vascular network Haller with its anastomoses, visualized during the clinical examination, identified on the photograph and observed in the thermographic image. Is worth mentioning that the image was obtained before the intervention proposed that, in the case of this lactating woman, was treated using the manual technique.
The images in Figure 3 were selected among the thermograms of the lactating women in the experimental group (electromechanical technique). We chose those that Best reflected anatomical and physiological aspects of the brest, such as the artefacts in the image that could conufse the evaluator. Two volunteers were selected. In Figure 3-A, the thermograms are illustrated before and after treatment (electromechanical technique) of a lactating woman with intense bilateral glandular engorgement that was still not breastfeeding. Before, the mean temperature of the breasts was $35.1^{\circ} \mathrm{C}$, with a gradient of $0.2^{\circ} \mathrm{C}$ after treatment.

In Figure $3-\mathrm{B}$, thermograms are shown pre-and post-treatment of a lactating woman with intense bilateral glandular engorgement that, initially, showed a temperature of $35.5^{\circ} \mathrm{C}$. After the massage and pumping, it was easy to drain the milk, the breasts were soft and there was pain relief. However, synthesis of milk and filling of the breasts again during the rest period was exacerbated, during which time the breasts remained uncovered for acclimatization. At the time of aquisition of the last image, the reflexo f ejection of milk occurred, leading to an artefact in the skin image At the time of acquisition of the last image, an ejection reflex of milk occurred, leading to an artifact in the image by the skin humidity (small arrow). After treatment, it measured $35.9^{\circ} \mathrm{C}$, with a positive variation of $0.4^{\circ} \mathrm{C}$. After treatment, the volunteer presented thermal asymmetry between the breasts; however, this could be related to the manipulation of the breasts, because the breast that received treatment last was hotter. 
a)

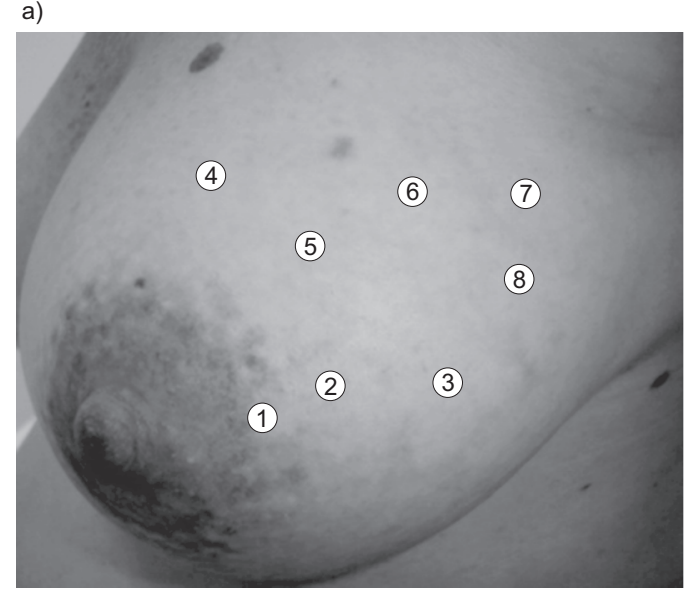

b)

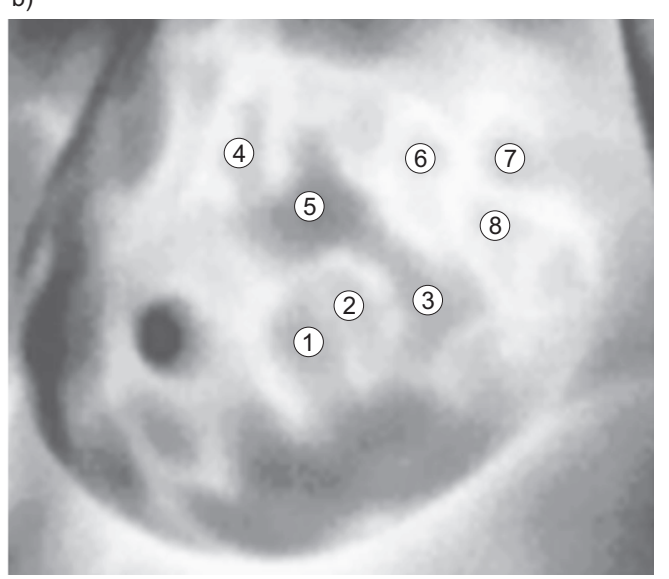

Figure 2 - Photograph (a) and thermogram (b) of the left breast of a lactating woman with moderate glandular engorgement (palette Rain 900), showing the Haller vascular network
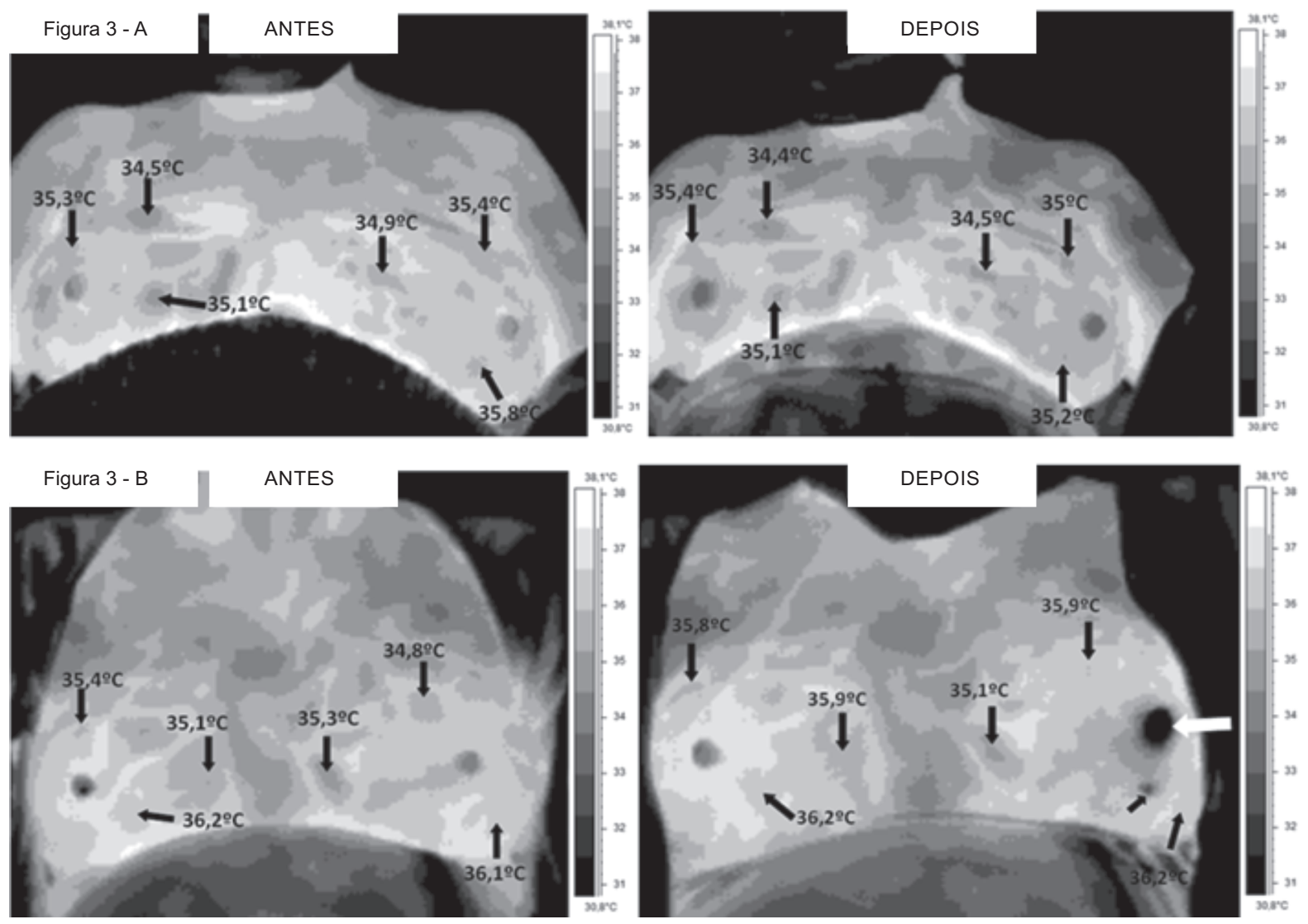

Figure 3 - In A, thermograms with intense globular BE. The images showed three tonalities of gray as follows: dark gray (colder temperature), medium gray (intermediate temperature) and light gray (warmer temperature). One observes the large thermal concentration in axillary and inframammary regions. In B, the breasts filled after treatment and there was an ejection reflex (small arrow, below the white arrow). Already the nipple (white arrow), presented itself with pallor, decreased perfusion and mild edema by use of the pumping machine

\section{Discussion}

For this study, the application of a technological instrument as a methodology became a challenge, principally for obtaining quantitative data, related to the physiological aspects of the breast. A new tool was used, thermography, which provided a new modality for imaging engorged breasts, which made it possible 
to monitor and evaluate the state of the breasts when faced with the type of treatment applied.

In view of the special moment that breastfeeding women experienced during the intervention, it was feared that the application of the proposed protocol could provoke stress in the volunteers, compared to the time for acclimatization, succession of thermograms, and electromechanical techniques for treatment. Changes in mood, tearfulness, personal insecurity and hormonal changes are common problems in this period ${ }^{(13)}$. Thus, we opted for only two images, one before and one after treatment. The periods of 15 minutes of acclimatization and post-treatment rest were used to orientate about breastfeeding and to clarify doubts about this process.

In relation to location of the $\mathrm{BE}$, two types lobar and lobar/ampullary accounted for $50 \%$ of the breastfeeding women in the control group, and $62.5 \%$ of the experimental group, that is, accounting for $56.25 \%$ of the sample. In another study ${ }^{(15)}$, this type of BE was also predominant and was encountered in $80 \%$ of the cases. With regard to the intensity of the lactating women with glandular BE, $42.85 \%$ were of the intense type and $57.15 \%$ were moderate.

Among the lactating women that presented with glandular BE, it was found that the breasts with intense engorgement were significantly warmer than in those with moderate $\mathrm{BE}$. When comparing the left and right breasts, the difference was $0.3^{\circ} \mathrm{C}$ and $0.2^{\circ} \mathrm{C}$, respectively, showing lower thermal variation. Among the lactating women that presented with moderate engorgement, the difference in temperature was $0.6^{\circ} \mathrm{C}$. But among those with intense $\mathrm{BE}$, the difference was $0.7^{\circ} \mathrm{C}$. Therefore, the temperature difference between the breasts of the same woman was lower when compared with the temperature difference between women, as well as between the two classifications of intensity. This was consistent with the literature, because one of the known properties of adipose tissue is to be a thermal insulator(22). Studies showed a variation in the proportion of glandular and adipose tissue, both among lactating women and those not lactating, and of the amount of the glandular tissues. It was also observed that there was no such variation between the breasts of the same woman ${ }^{(23)}$. It is worth mentioning that an important thermal asymmetry $\left(2.3^{\circ} \mathrm{C}\right)$ was detected between the breasts of a unique lactating woman, a fact that called for attention and merits further investigation.

After the interventions, there was a significant decrease in temperature in the experimental group. In the control group, this thermal gradient was not observed. This can be explained by the use of hands in the application of massage, which may have promoted greater transfer of kinetic energy. Although the experimental group experienced a reduction of temperature, in one of the lactating women (Figure 3-B) a temperature increase occurred after treatment using electromechanical techniques. In these two cases illustrated, although both had intense $B E$, the breast engorgement of volunteer 2 (Figure 3-B) was more severe and the greater in its intensity, a longer in time and greater in the intensity of the massage was offered to solve the problem and, consequently, the higher the glandular temperature. Thus, it is believed that the 15 minutes of rest were insufficient for thermal stabilization of the breast, in addition to the re-filling that occurred during the rest period. This event suggests that favor empty breasts milk production in lactating women, with milk production exacerbated.

Intrinsic and extrinsic factors exist that can interfere with the analysis of the thermograms. In this study, skin humidity provoked by the milk ejection reflex, as well as the Haller network, could confound the evaluator. The vasuclar Haller network is described as an anastomotic circle around the auréolo-papillary complex, formed by the superficial veins which dilate intensely in the puerperal process ${ }^{(24)}$. It was observed that the superficial vascular network covers the entire mammary gland and inspection by physical examination became essential to its identification, as it helped in the interpretation of images in the regions of interest, namely, cooler spots of the breast. The Haller network is quite expressive in the puerperal breast, requiring a careful inspection of the thermographic image and familiarization of the evaluator with the vascular anatomy, because large vessels "saturate" the images and are obstacles in the investigation(6).

\section{Conclusions}

In her professional practice, the nurse has care permeated by technology. She also has the opportunity to contribute with research, propose and develop innovative actions to improve care for people, adding technical subsidy of optimization to nursing care, specifically in the prevention and treatment of lactational BE.

It was verified that thermography was a comfortable, innocuous and safe technique, but requires an environment suitable for the study. It provided greater physiological knowledge of the puerperal breast, and was 
able to differentiate breasts with moderate and intense, glandular BE, namely, it showed that the greater the intensity of swelling, increased also the temperature of the breast. The thermal asymmetry between the breasts and the temperature gradients at points of interest indicated possible pathologies, dysfunctions, perfusions, or functional abnormalities, which were mostly imperceptible on physical examination. In this work, thermography was used as a new technology in the Field of medical imaging, in which the primary advantage was the measure of the temperature gradients in various points of interest, as well as to verify the thermal symmetries that were produced by the treatment techniques for BE of massage and electromechanical pumping. The adopted method provided reliable data and subsidized clinical examination in the methodological process of this research.

Compared to a standard method, the use of cold packs in the treatment of $B E$, such steps to decrease edema, vascularization and pain, there is evidence that treatment by electromechanical techniques also reduced the temperature of the breasts, promoting the decreased glandular vascularization and consequently the production of excess milk, providing comfort and pain relief in lactating women.

Finally, electromechanical techniques proposed and thermography, within their limitations in this pioneering study, showed promising results in the investigation of treatment of breast engorgement during lactation. Additionally, thermography may also indicate clues for other mammary problems such as cancer, circulation in vessels and peripheral arteries, and internal inflammation.

\section{References}

1. Almeida JAG. Amamentação: um híbrido naturezacultura. Rio de Janeiro: Fiocruz; 1999.

2. Carvalhaes MABL, Parada CMGL, Costa MP. Fatores associados à condição do aleitamento materno exclusivo em crianças menores de 4 meses, em Botucatu, SP. Rev. Latino-Am. Enfermagem. 2007;15:62-9.

3. Giugliani ERJ. Problemas comuns na lactação e seu manejo. J Pediatr. 2004;80(5)suppl: 147-54.

4. Book OR, Guralnik L, Keidar Z, Gaitini DE, Engel A. Pitfalls of the lactating breast on computed tomography. J Comput Assist Tomogr. 2004;28(5):647-9.

5. Shimo AKK. Mama Puerperal: aspectos preventivos e curativos do ingurgitamento mamário. [dissertação]. Ribeirão Preto: Escola de Enfermagem de Ribeirão Preto da Universidade de São Paulo; 1983. 163 p.
6. Balbinot LF. Termografia computadorizada na identificação de trigger points miofasciais. [Dissertação Mestrado em Ciências do Movimento Humano Biomecânica]. Florianópolis: UDESC; 2006. 126 p.

7. Nunes LAO, Andrade ACC Filho, Sartori JL. Diagnóstico de Diversas Patologias com Tecnologia Brasileira. Rev Micro e Nanotecnol do Pólo Industrial de Manaus. [Internet]. 2007; (10) [acesso 27 abril 2013]. Disponível em: http:// www.suframa.gov.br/minapim/news/visArtigo.cfm? Ident $=419$ \&Lang $=\mathrm{BR}$

8. Bezerra LA, Lima RCF, Lyra PRM, Araújo MC, Santos FGC, Bezerra KM. Uma comparação entre temperaturas de mamas obtidas pelo método dos volumes finitos em malhas não-estruturadas e aquelas adquiridas através de termogramas de pacientes de hospital público localizado em clima tropical. $8^{\circ}$ Congresso Iberoamericano de Engenharia Mecânica; outu 2007. [acesso 31 março 2012]. Disponível em: <http://congreso.pucp.edu.pe/ cibim8/pdf/03/03-29.pdf

9. Rustemeyer J, Radtke J, Bremerich A. Thermography and thermoregulation of the face. Head \& Face Medicine. [Internet]. 2007, 3:17 [acesso 20 fev 2010]. Disponível em: http://www.head-face-med.com/content/ 3/1/17

10. Nyirjesy I. Breast Thermography. Clinl Obstet Gynecol. 1982;25(2):401-8.

11. Birnbaum SJ. Breast temperature as a test for pregnancy. Obstet Gynecol. 1966;27(3): 378-80.

12. Menczer J, Eskin BA. Evaluation of post-partum breast by thermography. Obstet Gynecol. 1969;33(2):260-3.

13. Barros SM. Enfermagem no Ciclo GravídicoPuerperal. Barueri: Manole; 2006. 231 p.

14. Walker M. Breastfeeding and engorgement. Breastfeeding Abstract. 2000;20(2):11-2. [Internet]. La Leche League Internacional [atualizado 31 ago 2006]. [acesso 8 ago 2012]. Disponível em: http://www.Illi. org/ba/nov00.html

15. Silva IA. Inovação no tratamento do ingurgitamento mamário - o uso do vibrador elétrico para massagens. Acta Paul Enferm. 1996;9(1):61-70.

16. Gomes MB, Guimarães FC, Guimarães SMR, Claro NAC. Limiar de dor à pressão em pacientes com cefaléia tensional e disfunção temporomandibular. Cienc Odontol Bras. 2006; 9(4):84-91.

17. Agência Nacional de Vigilância Sanitária (BR). Banco de Leite Humano: funcionamento, prevenção e controle de riscos. Brasília: Agência Nacional de Vigilância Sanitária; 2008. 160 p.

18. Margato MP, Lucio CC, Heberle ABS, Nohama P. Pesquisa e Desenvolvimento de Produto para Auxiliar no Tratamento de Ingurgitamento Mamário em Lactantes. 
Anais do Congresso Internacional de Ergonomia e Usabilidade de Interfaces Humano-Tecnologia: Produto, Informações, Ambiente Construído e Transporte, 2010. Rio de Janeiro; 2010.

19. Vinha VHP. O livro da amamentação. 2. ed. São Paulo: CLR Balieiro; 2002. 91 p.

20. IACT, Thermography Guidelines: Standards and Protocols in Clinical Thermographic Imaging [Internet]. Internacional Academy of Clinical Thermology; Sept 2002. [acesso 20 junho 2012]. Disponível em: http:// www.iact-org.org/professionals/thermog-guidelines.html 21. Brioshi ML, Cheren AJ, Ruiz RC, Sardá Júnior JJ, Silva FMRM. O uso da termografia infravermelha na avaliação do retorno ao trabalho em programa de reabilitação ampliado (PRA). Acta Fisiatr. 2009;16(2):87-92.

22. Fonseca-Alaniz MH, Takada J, Alonso-Vale MIC, Lima FB. O tecido adiposo como ógão endócrino: da teoria à prática. J Pediatr. 2007;83(5):suppl S192-S203

23. Geddes DT: Ultrasound imaging of the lactating breast. Methodology and application. Int Breastfeed J. 2009;4:4.

24. Rolim LMO, Figueiredo ALM. Anatomia da mama e fisiologia da lactação. Bol SOPER. [Internet]. [acesso 5 out 2010]. Disponível em: http://www.soperj.org.br/ revista/detalhes. asp? $\mathrm{id}=22$ 